University of Windsor

Scholarship at UWindsor

2012

\title{
Judicial Settlement-Seeking in Parenting Disputes: Consensus and Controversy
}

Noel Semple

University of Windsor, Faculty of Law

Follow this and additional works at: https://scholar.uwindsor.ca/lawpub

Part of the Family Law Commons

\section{Recommended Citation}

Semple, Noel. (2012). Judicial Settlement-Seeking in Parenting Disputes: Consensus and Controversy. Conflict Resolution Quarterly, 29 (3), 309-332.

https://scholar.uwindsor.ca/lawpub/8 been accepted for inclusion in Law Publications by an authorized administrator of Scholarship at UWindsor. For more information, please contact scholarship@uwindsor.ca. 


\section{Judicial Settlement-Seeking in Parenting Disputes: Consensus and Controversy}

\section{Introduction}

A judge is, traditionally, an authoritative decision-maker. Moses' biblical account of his work as a judge -- "the people come to me [and] I decide between one person and another" -would probably strike most laypeople as an accurate description of the job. (Exodus 18:13-16) However, it has long been known that many judges also play a different role: encouraging people to resolve or abandon their disputes. Without making orders, and sometimes without even making statements about the law, many judges try to bring about voluntary settlement of the disputes which come before them. (Resnik, 2000, p. 925; Galanter, 1985; Roberts, 2002, p. 21.)

Judicial settlement-seeking in child custody and visitation disputes is the focus of this paper. It argues that the pursuit of settlement is an important, but ambiguous and under-theorized aspect of the judicial role in this context. The paper begins by introducing this area of law and the judicial role in these cases. It then reports findings from the author's interviews with ten family court judges, and eighteen other family law professionals, in the Toronto and New York City areas. All of the respondents in the sample reported that family court judges actively seek to convince parents to voluntarily resolve their disputes, primarily in pre-trial conferences. Most judges used evaluative techniques to seek settlement, in many cases offering predictions of the outcome of the dispute if it were adjudicated. However, a substantial group of respondents also described facilitative approaches to settlement-seeking, in which the judge's opinion is deemphasized in favor of the parties' responsibility to create their own solution. 
The paper then identifies two controversies about judicial settlement-seeking in parenting cases which emerged from the interviews and literature review. Whether a single judge can both encourage settlement and subsequently perform any necessary adjudication of the same matter is a question openly debated in the literature and by practitioners. An important issue which is thus far less overt in the discourse is the reconciliation of the best interests of the child principle with the fundamentally adult-centered pursuit of settlement. This paper concludes that the consensus of the respondents regarding the importance of encouraging settlement papers over significant differences of opinion about the role of the judge.

\section{Custody and Visitation Disputes: Toronto and New York}

Custody and visitation disputes arise when parents part company, and cannot agree about how to allocate the rights and responsibilities of parenting between them. Technically, "legal custody" refers to the right to make legal decisions on behalf of a child. "Visitation," which is known as "access" in Canadian law, refers to the right to spend time with and receive information about a child. Custody disputes and visitation disputes are generally analyzed together as a conceptual unit, insofar as they are both primarily about which adults will have physical control over a child or children for which blocks of time. Today, the outcome of these disputes is usually a calendar or "parenting plan" which allocates decision-making authority and the child's time. (Silbermann, 2008, p. 17).

Throughout the Western world, the law's response to custody and visitation disputes is the "best interests of the child" principle (Blair and Weiner, 2006, p. 247). The legally correct outcome is that which is best for the child or children involved. The parties are not, in principle, permitted to put forward claims about their own rights and interests; they must argue that their 
preferred outcomes are best for the child (Semple, 2010). This feature distinguishes custody and visitation law from almost all other forms of civil litigation (Reece, 1996, p. 274).

Despite the proliferation of alternative dispute resolution options, judges retain the ultimate authority to apply the best interests test in custody and visitation disputes. ${ }^{\text {i }}$ Best interests decision-making is challenging for judges due to ambiguous statutes and the difficulty of assessing the relevant information (Guggenheim, 2005). The applicable statutes provide slender guidance or restraint to judicial discretion in this context. For example, Ontario's Children's Law Reform Act provides that, in determining best interests in the custody and visitation context, "all the child's needs and circumstances" must be considered. The statute lists eight factors which are relevant, such as "the ability of each person applying for custody of or visitation to the child to act as a parent" and "the love, affection and emotional ties" between the child and the adults. However these factors are not exhaustive and are in any case so broad that they do not substantially limit the scope of the inquiry. Likewise, New York's Domestic Relations Act statute says that decisions must be made having "regard to the circumstances of the case and of the respective parties and to the best interests of the child."

While best interests decision-making is difficult, settlement is relatively simple. With very limited exceptions, the parties are free to resolve their dispute on any mutually acceptable terms, at any time. If they do so, the family justice system ceases to be involved unless there is a reason to believe that the child is in need of protection. Either adult party may also withdraw from the litigation at any time if he or she wishes to concede. The consent of the child is not necessary, in any North American jurisdiction, for the settlement of a custody or visitation dispute to be binding. 


\section{The Judicial Role in Settlement-Seeking}

There is ample North American literature about judicial settlement-seeking. Academics tend to be critical of the practice (for example Resnik, 2000; Tornquist, 1989;Menkel-Meadow, 1985), while settlement-seeking judges have defended their work in print (Brazil, 1987; Hogan, 1991; Baer, 2001). The leading empirical study was conducted by Stacy Burns, who conducted ethnographic observations of judicial mediations in tort cases (Burns, 2000, 1998, 2001). However there is a dearth of writing about judicial settlement-seeking methods in family law cases, with the exception of a handful of articles by judges, either recounting their personal experiences (Lieff, 1976; Gove, 1999; Rolland, 2009, p. 10) or describing local court-based judicial mediation programs (Landerkin, 1997, Goss, 2004). Settlement-seeking is clearly identified as a function of modern family courts (Bailey-Harris, Barron, and Pearce, 1999), but it is most often attributed to non-judicial professionals such as mediators (Salem, 2009).

Most North American scholarship about judges' work in parenting disputes has portrayed them not as settlement-seekers, but rather as decision-makers, managers, or team leaders. One body of research contrasts judicial decision-making in divorces to private ordering, in which the parties settle their disputes out of court (Mnookin and Kornhauser, 1979, p. 956). For example, Ralph Cavanagh and Austin Sarat argued that actual judicial decision-making is less important than the threat of judicial decision-making, which causes the parties to settle without going anywhere near the judge (Cavanagh and Sarat, 1980). Another well-populated line of scholarship focuses on whether and why judges award custody to mothers more often than to fathers, or sole custody more often than joint custody (for example Artis, 2004; Millar, 2009). Andrew Schepard identified a transformation in the custody judge's role from "fault finder" to "conflict manager." He analogizes the modern parenting court to a bankruptcy court, seeking to "get the managers 
[parents] to voluntarily agree on a parenting plan rather than impose one on them" (Schepard, 2000, p. 396). Family court judges are also sometimes referred to as "team leaders," coordinating and deploying various other professionals in a therapeutic effort to assist a family (Johnston, Roseby, and Kuehnle, 2009, p. 230-232; Spinak, 2009).

England has produced much of the research about judicial settlement-seeking in custody and visitation cases. The first judge-led divorce "conciliation" efforts were introduced in the Bristol courts in 1977 (Roberts, 2008, p. 41), generating a lukewarm response from scholars in the 1980s. (Roberts, 1983; Davis, 1988). In the late 1990s, a group from the University of Bristol Faculty of Law conducted extensive empirical observations and interviews in south-west England family courts. They identified settlement-seeking as a major goal of judges and other court staff (Pearce, Davis, and Barron, 1999; Bailey-Harris, Barron, and Pearce, 1999). So reluctant were family courts to actually adjudicate parenting cases that Gwynn Davis and Julia Pearce analogized them to "butcher's shop[s] which will not sell meat" (Davis and Pearce, 1999, p. 460). Most recently, Liz Trinder and Joanne Kellett compared dispute-resolution mechanisms in English family courts in terms of the degree of judicial involvement. They identified a "high judicial control model" for settlement-seeking, and compared it to alternatives in which social workers take the lead (Trinder and Kellett, 2007, p. 324). These authors studied an exemplar court in which the judicial control model was used, but did not indicate its overall prevalence in English family courts (Trinder et al., 2006). While the British studies have identified and provided a preliminary critique of judicial settlement-seeking in parenting cases, they have not yet explored the techniques by which settlement is pursued. 


\section{Research Methodology}

The author interviewed twenty-eight family justice system professionals in the Toronto and New York City areas in 2010. ${ }^{\text {ii }}$ Ten of these were sitting or recently retired family court judges who heard custody and visitation disputes on a regular basis. Three of the Toronto judges preside in Superior Court, which deals with parenting and other disputes arising from divorces. Two were from the provincial court (the Ontario Court of Justice), which deals with all other parenting disputes, including those arising from non-marital relationships. The other five judges were sitting or past members of the Matrimonial Part of the Supreme Court of New York, which grants divorces in that state. The eighteen other interviewees were lawyers, custody evaluators, mediators, and law professors in the two cities. These family law experts were asked, among other things, about the judicial role in these disputes.

Toronto and New York were chosen as comparators because they have similar laws pertaining to custody and visitation disputes but significant and interesting differences in the dispute-resolution environments and procedures applied to parenting cases. This research began in an exploratory vein, as a general inquiry into custody and visitation dispute resolution processes inside and outside of court. Judicial settlement-seeking was a theme which emerged consistently in the interviews in both cities.

The interviewees were identified through a process of network sampling. The author wrote letters to individuals prominent in the field; they provided references and introductions to others. Semi-structured, topical interviews lasting between 45 and 90 minutes were conducted. The sample was purposive rather than random, and the findings from this research should not therefore be considered representative of all family judges in the communities studied. Nor do these findings permit conclusions about what proportion of family judges pursue settlement, and 
what proportion confine themselves to a more traditional decision-making role. However, the data reported here may be considered a helpful illustration of how and why some family judges pursue settlement in parenting cases, and of the questions which this practice poses for judges and policy-makers.

\section{II. "Settling, That's Our Job"}

All of the ten judges in the sample said that they actively seek to bring about consensual settlements in their custody and visitation cases. For example, New York judge PP said she makes "every effort to encourage settlement before we have a trial." A Toronto Superior Court judge, asked whether he consciously seeks to produce settlement, said "absolutely, I think most of us [do so]." In the words of provincial court justice BB, "every court appearance is an opportunity to settle the case." His colleague at the same court said that if the litigants

think they have a chance of settling, that's our job, that's what we're here for... if somebody's going to go to trial over custody and access, I really want to feel that I gave it my best shot at settling it.

To many judges, "success" in a parenting case means settlement. For Justice CC of the Toronto Superior Court, the fact that "probably close to $80 \%$ resolve" means that his court has "a high success rate in conference[s]." He added that "if your conferencing works, then your trial numbers go way down. If your conferencing works, your motions go way down.”

The primary venue for the pursuit of settlement, in both Toronto and New York, is the pre-trial conference. In both jurisdictions, the litigants must personally attend these meetings, along with their lawyers if they are represented. In both jurisdictions, the statutory purposes of the conferences are broad, allowing judges to choose whether or not to pursue settlement. In 
Ontario's Family Law Rules, "exploring the chances of settling the case" is listed among the 19 possible goals which a judge can pursue in a pre-trial conference (Rule 17). New York's equivalent permits the judge to seek "simplification and limitation of issues" and "any other matters which the court shall deem appropriate" (New York Codes, Rules, and Regulations, Title 22, s. $202.16(f))$.

The pre-trial rules also permit a judge to use the conference for other purposes such as monitoring compliance with disclosure requirements. However the author's interviewees universally stated that the pursuit of settlement is either one of the primary purposes, or the primary purpose, of the pre-trial conferences. In the words of one experienced New York matrimonial attorney, "the first thing" that judges ask in a pre-trial conference is "how can we settle?" In a Toronto family court conference, according to provincial court judge DD, "everybody has a positive obligation to try and work things out ... the first court appearance and the subsequent court appearances are everybody sitting down and talking about how to resolve it."

However, some interviewees drew a distinction between themselves and more traditional judges, suggesting that settlement-seeking is not practiced consistently by all family court judges. Justice CC, at the Toronto Superior Court of Justice, said that some of his colleagues at other Ontario courthouses “don’t believe that [settlement-seeking] is a judicial function, that judges are to decide cases, and they are not to try to help people to settle their cases." Justice BB of the provincial court was, like the other interviewees, an active settlement-seeker. However, he said that some judges "treat settlement conferences as preparation for trial... their settlement conferences will be things like 'How many witnesses have you got? How long do you think 
you'll need? Are there any expert reports?" Settlement-seeking appears to be prevalent, but not universal practice among family court judges in these jurisdictions.

\section{Pre-trial Conference as Evaluative Mediation?}

Is judicial settlement-seeking in parenting cases a form of mediation? Mediation is defined as the attempt by a neutral third party to bring about voluntary and consensual settlement of a dispute, (Folberg, Milne, and Salem, 2004 at 8). The judicial pursuit of settlement in parenting cases technically meets this definition. Moreover, the settlement-seeking techniques described by the interviewees are consistent with evaluative and facilitative mediation, two of the three primary variants identified in the literature. (Folberg, Milne, and Salem, 2004, p. 8).

In evaluative mediation, the mediator assesses the strengths and weaknesses of the parties' positions against an external criterion, usually the law. This method sometimes involves predictions about what the adjudicated outcome would be, and in more aggressive versions also includes specific proposals about the terms upon which parties should settle (Riskin, 1996, p. 27). Several scholars have suggested that the evaluative approach is typical of judicial settlement-seeking, (Brunet, 2002; Press, 1998; Lambros, 1984) and one has claimed that the judicial settlement conference was the original model for all evaluative mediation (Zumeta, 2000).

This was generally the case among the judges interviewed. Toronto Superior Court Justice CC said that

people should be coming to judges because they want some neutral evaluation and recommendation as to how they should resolve their issues ... I strongly believe that when I see people, I should give them 
my evaluation of their case, with the understanding that I don't know everything.

The adjective "evaluative" was also used by one provincial court judge and one New York judge as a valid descriptor their settlement-seeking styles. An Ontario provincial court judge said that parties in conferences would at times be "pressed by the judge to make a decision in a certain way." New York judge PP is likely to critically evaluate the positions taken by the litigants at some point in the conference:

if one side is taking a position ... and they're not willing to reach common ground, then I'll say 'well, you know, if we went to trial I would probably go ... the other way on this... not that I'm prejudging the case' ... to make them sort of rethink that, and maybe be willing to compromise and give something else up instead.

The judges were inclined to offer "hedged" evaluations, which were less explicit than an outright prediction of what would happen at trial. These hedges help avoid the perception that the matter has been "prejudged" before the parties were allowed to have their day in court. An evaluative statement is likely to be preceded with a phrase such as "assuming this is everything that comes in ...," or "if ... the evidence and the facts are accepted in your way...". Having delivered a negative evaluation, Justice PP would hasten to say: 'I'm more than willing to listen to your proof and you can certainly try to convince me you're right on that point and I will keep an open mind about it." Conversely, another judge said that she would follow a positive evaluation with the proviso "I don't yet know what facts you will be able to prove.,"iii 
Two New York judges said that they point out to each side both the strengths and the weaknesses of their respective cases. As the literature has recognized, a judge seeking settlement has an incentive to emphasize weaknesses rather than strengths when speaking privately to one side (Oesterle, 1983). Doing so encourages each side to make concessions, bringing them both toward a compromise position in the center. Stacy Burns found that judicial mediators play the role of "devil's advocate, attempt[ing] to induce doubt in each side by making distinct pronouncements selectively to each about the facts, evidence, precedents, procedures and likely prospects of the case" (Burns, 2001, p. 241). Willam Adams also suggests that most judicial evaluations in pre-trial conferences "involv[e] throwing cold water on the case" (Adams, 1993, p. 448). One interviewee, a New York family law professor, reported having observed this behavior among judges in pre-trial conferences.

The methodology of this study did not permit comprehensive evaluation of this theory. It is worth noting that the "cold water" strategy of judicial settlement-seeking would seem to require speaking to each side individually, a practice known as "caucusing." If the parties are in the same room, then any statement by the judge which is "cold water" to one side would also be "hot water" to the other. Caucusing has been described as the "hallmark of the evaluative method" (Baer, 2001, p. 136), but only some of the judges in the sample reported that they use it.

\section{Pre-trial Conference as Facilitative Mediation?}

There is another path to settlement, which does not involve predicting court outcomes or telling the parties what they ought to do. Facilitative mediation emphasizes that the parties themselves are responsible for the terms of their settlement. The role of the neutral is not to predict outcomes or critically analyze positions, but rather to help the parties to communicate with each other (Folberg, Milne, and Salem, 2004, p. 14). One recent article supported 
facilitative and non-judgmental judicial settlement-seeking, arguing that in pre-trial conferences judges should "refrain from expressing any opinion on the legal merits of the case" (Otis and Reiter, 2006 at 369). The facilitative approach can be used consistently by a judge as a matter of professional philosophy, or it can be deployed selectively depending on the circumstances. Reflecting the idea that evaluation and facilitation are different tools in the same box, one Toronto family lawyer described good judicial case conferencing as "to facilitate and direct and maybe sometimes to twist some arms."

Facilitation seems to be the first line of settlement-seeking for some judges, with evaluation deployed as a fall-back. New York judge PP, who generally evaluates at some point during the conference, nonetheless said that she begins each conference by asking "what both sides want, and what they're looking for, and then seeing if you can find some kind of a ground between them." New York matrimonial attorney LL said that this is the typical opening move for a family judge in a pre-trial conference:

The first thing they do in a settlement conference is ... try and negotiate a settlement that's more based on what the parties can agree on, as opposed to saying what they are going to do.

Some of the judges' comments reflected the facilitative idea that healthy communication between the parties is as important as or more important than the terms of the agreement they reach. This is compatible with the prevalent, although contested, proposition that family courts must not only resolve legal issues but also improve family dynamics (Lee, 2007, p. 648).

Superior Court Judge EE, sitting in a Toronto suburb, said that he is reluctant to offer opinions about trial outcomes in the absence of a full factual record. Instead, he said, "what I 
encourage people to do, and what I think is far more beneficial, is if within the framework of the law and with my assistance, they will come to their own agreement." Justice UU, a matrimonial and administrative judge from a New York suburb, emphasized the primary importance of creating "good feeling" between the parties which will survive the litigation itself, especially if there are children. He said that it was "very important to try to create a dialogue," given the impossibility of continuing judicial management of the post-divorce family.

Another reason to avoid excessive evaluation is the technical difficulty of predicting a trial outcome at a pre-trial conference. In addition to the inherent challenges of identifying a child's best interest, there is also uncertainty about what evidence would be admissible were the matter to be adjudicated. New York judge MM said that she tries to avoid predicting trial outcomes, "because I really don't know what I would do if it came to trial."

One way to encourage settlement without evaluating the merits of the case is to emphasize the general costs of litigating and the benefits of settling (Lieff, 1976, p. 312.). Toronto Superior Court Judge CC said

I generally give the same message, not about the result, but I tell people that there's a cost involved, emotionally and financially, to proceeding with their litigation, and if the differences between them are not so great that it makes any sense to me to proceed on, and the net benefit to either one of you is not worthwhile, I have some standard lines which I'm sure, after a while, the lawyers get tired of...

New York matrimonial attorney KK confirmed that this approach is often deployed in her jurisdiction as well. Especially when the parties are not represented by lawyers, the judicial 
message "would be more sort of a general, "much better for you guys to decide the fate of your children and your money than this stranger in black robes' ... less of a specific 'this is how you should settle the case."

New York judge MM said that she has a standard speech which she delivers to all parents with a significant custody dispute. The central message of the speech is that "it is far better for them, and more importantly for their kids, for them to settle" the dispute rather than trying it. "If you love your children," Judge MM tells the litigants, "you will resolve this by agreement and not by having a trial." Although this speech is customized according to the circumstances, it is consistent enough that Judge MM had it transcribed and printed. She distributes it when campaigning for re-election, to illustrate to voters her approach to family law.

Justice Abraham Lieff introduced family court pre-trials to the Toronto Superior Court of Justice in the mid-1970s. In a 1976 article, he described his standard approach for promoting settlement of custody issues. After having the parties agree that they want their child to "mature as a good Canadian," Justice Lieff would then ask:

How do you expect to attain that objective if you and your wife are going to wrangle about the child's upbringing and if you keep resorting to the courts constantly? How can you expect a child to be truthful, if from time to time the child hears you accuse each other of lying? (Lieff, 1976, p. 314).

Justice Lieff was able to provide a list of 15 statements and questions which he posed to parents in pre-trial conferences. ${ }^{\text {iv }}$ Like New York Judge MM who was able to have her "standard speech" transcribed, Justice Lieff appears to have operated on the assumption that most or all 
parents need to hear the same message about their children. This is a clear departure from the evaluative approach, which in principle involves customized diagnosis and prescription.

The author had the opportunity to observe a pre-trial conference in which Ontario Superior Court Judge EE was presiding and using a facilitative technique. The parties were involved in litigation about their 12 year old son. They were in agreement with regard to the majority of the parenting schedule, which involved one calendar for the school year and a different one for the summer. The only outstanding issue of dispute was whether the summer schedule should begin on (i) the last day of school, or (ii) on the first Sunday thereafter. Judge EE began the conference by giving a short speech about the parties' son. Although acknowledging that he had not met the child, he expressed confidence that the son would want the parties to resolve their dispute. He did not express an opinion about which of the two alternatives would be more consonant with the best interests of the child. The lawyers then made brief submissions. EE thanked them and invited the parties to discuss the parenting issue and attempt to resolve it. EE and the author left the room for 15 minutes, at which point we were called back in by the court clerk. Mission accomplished: the parties had settled.

Within the facilitative vein, some judges sought to shift the perspectives of the parties away from their grievances against each other and toward their children's interests. Toronto Superior Court judge AA believes that

A large number of parents ... lose sight of children's need and interest in having a strong relationship with the other parent. And when I see that -and I do see that fairly regularly -- I push hard to get them off that position. I speak very emotively about it, and the damage that they're 
doing to the child, and try to get the tears flowing. Because it's a big problem, and I just want to make sure that they realize that they're going down a very dangerous path, and that they might have to do some serious rethinking.

This perspective-shifting often seems to involve "emotional labour," a phenomenon identified by sociologist A.R. Hochschild and recently applied to the judiciary by Sharyn Anleu and Kathy Mack. Emotional labour requires the worker to both "maintain a certain emotional display" and "produce an emotional state in another person" (2005, p. 592). Anleu and Mack found Australian trial judges doing emotional work in order to maintain the reality and appearance of impartiality while ensuring that litigants and observers perceive the process as legitimate and just. Ontario provincial court judge BB said that settlement-seeking in a parenting case requires the judge to "connect with [the parents] on an emotional level." Judge MM said that one or both parties usually starts crying when she delivers her speech urging settlement. This used to alarm her, but now she considers it a good sign that she's "reached them." For at least some family court judges, settlement-seeking requires "getting the tears flowing" -- a more intense and activist form of emotional labour than that described by Anleu and Mack.

To return to the question posed above, is judicial settlement-seeking in family court pretrial conferences a form of mediation? Some scholars writing about non-family pre-trial conferences have done so (for example Rolland, 2009, p. 9; Burns, 2000 at 16), others have noted the similarities between the two phenomena without equating them (Welsh, 2001, p. 58; Baer, 2001, p. 146). A family court judge in a pre-trial conference, like a professional mediator, is a neutral third party who seeks to convince litigants to settle their dispute without having the power to impose terms. Like mediators, these judges use evaluative and facilitative approaches 
to do so. Indeed, some of the interviewees were somewhat willing to accept the "mediation" label on their work. Judge EE said that, although pre-trial conferences are not "structured" as mediation, "by and large they are forms of mediation, at least I perceive them that way... I consider it judicial mediation." Judge AA also accepted that judicial mediation can occur at pretrial conferences.

However most interviewees stated that they are not mediators, often saying that their evaluative style or inherent judicial authority distinguishes them from mediators. New York matrimonial judge PP said that, contrasted to judicial settlement-seeking, mediation is "much more passive... more of a facilitated discussion between the parties, without predicting an outcome." Justice TT had recently retired from the New York matrimonial court. As a judge in pre-trial conferences, she said, she was acting as a "settler," in contradistinction to her current work as a mediator in private practice (Sander, 1999, p. 22 draws a similar distinction). As a judicial "settler" her work was focused on legal issues and rights, and was more evaluative. As a private mediator, she focused more on interests, which is to say the psychological and material desires of the parties. ${ }^{\mathrm{V}}$

Comments made by experienced Toronto divorce lawyer XX on this point reflect the contested definitions of the word "mediation." He said that "some judges get horrified at the suggestion they're going to be turned into mediators" when they join the family bench. XX said that, although family judges need training in "how to mediate," nonetheless "they're not mediators." 


\section{Judicial Settlement-Seeking: Practical Controversies}

\section{One Judge or Two?}

Whether or not the judges in a particular court choose to pursue settlement, they remain responsible for decision-making in those cases which do not settle. If a judge's efforts to encourage settlement are unsuccessful and a trial becomes necessary, will that same judge preside and adjudicate? Or should the case be assigned to a second, previously uninvolved judge if and when adjudication is required?

The relative merits of these "one-judge" and "two-judge" models have been debated in the literature, but without apparent reference to the specificities of family court or parenting disputes. The central arguments for the two-judge model pertain to prejudgment and coercion. (Alfini, 1999; Colatrella, 2000, p. 415-6; Cratsley, 2006 at 571-6). If a parent enters a pre-trial conference seeking sole custody of her child, and the judge conducting the conference encourages her to settle for joint custody, she has the right to refuse to do so. Procedural justice, in principle, affords her the right to go to trial and present the case that sole custody would be in the child's best interest. However, if the judge presiding at that trial is the same one who suggested joint custody in the conference, she may doubt her chance of obtaining a fair hearing, and feel coerced into accepting whatever the judge is proposing. Even if the judge totally clears her mind of what occurred in the conference and approaches the matter without any preconceptions, it is understandable that the parent would be sceptical. Justice UU, who exercised administrative duties in a New York suburb following the one-judge model, said that he had seen multiple letters from litigants complaining that their matters had been "prejudged" in pre-trial conferences. Some scholars have suggested that, in response to these concerns, the two- 
judge model is becoming increasingly prevalent. (Alexander, 1994, p. 653; Brunet, 2002, p. 232).

However, judges and a few scholars defend the one-judge model on the basis that it represents a more efficient allocation of judicial labor (Resnik, 1982, p. 435). If a second judge is assigned for trial, that judge must spend time learning the case, whereas the pre-trial judge is already familiar with it. It is also said that the one-judge model is more effective in bringing about pre-trial settlements (Hogan, 1991at 439). A survey of California judges found that $82 \%$ approve of the one-judge model (Robinson, 2006, p. 343). The American Bar Association's Model Code of Judicial Conduct permits both models, while cautioning judges to be "mindful of the effect settlement discussions can have, not only on their objectivity and impartiality, but also on the appearance of their objectivity and impartiality" (American Bar Association, 2007, p. 21).

The author found the one-judge and the two-judge pre-trial conference models being used and debated within the sample. In Toronto, the two-judge model has prevailed in family litigation since pre-trial conferences were first introduced in the 1970s (Stevenson, Watson, and Weissman, 1977, p. 594; Lieff, 1976, p. 311). In New York, by contrast, a single judge will be responsible for the case from beginning to end, including all pre-trial conferences and the trial if one occurs. New York matrimonial attorney LL confirmed that the judge in the pre-trial conference will "almost always" be the one who will hear the trial if it occurs. Nor, she suggested, do they necessarily feel the need to conceal their decision-making power while seeking settlement:

Sometimes judges will try to settle cases by saying ... 'you're talking to the trier of fact, so I'm telling you know that everything you've told me 
today doesn't make me want to believe your client, so really you should settle.'

New York judge MM said that, so long as the parties are represented by counsel, she will ask their permission to personally conduct the pre-trial conference. Although the parties know that she will also hear the trial if necessary, they almost never object.

New York's one-judge system allows pursuit of settlement to continue beyond the pretrial conferences, and into the trial itself. Justice TT, recently retired from the New York bench, said that during recesses from the trial itself she would often take the parties aside, tell them what facts she was finding, and discuss settlement possibilities. According to Justice PP:

a lot of times the best way to settle a case is to call your first witness. .... if we start the trial and we've got somebody testifying and it's just obvious that they're not going to go anywhere with their case, then I'll just call a recess, and call the attorneys into my chambers, and try to get them to settle at that point, because they've had their chance to start their case at least.

New York matrimonial attorney LL said, "some of the judges ... don't want to know what's going on in the case until the case is actually presented before them at trial, because in settlement you do discuss things that are not going to become evidence." A New York judge who wishes to take a more hands-off approach to settlement-seeking may assign his or her "court attorney" to conduct the pre-trial on his or her behalf. A court attorney is a lawyer employed by the court who, among other duties, can be tasked with conducting pre-trial conferences. However, by contrast to a confidential mediator or a pre-trial judge, the court attorney is not 
independent from the presiding judge. A court attorney conducting a pre-trial conference will usually remain in communication with the presiding judge, and what happens in a court attorney conference is not confidential from that judge. This system is not, therefore, a complete response to the prejudgment and coercion issues.

The lower rates of self-representation in New York might account for the prevalence of the one-judge model. While in New York the majority of custody and visitation litigants are represented by lawyers, in Toronto the majority are self-represented. While hard city-specific quantitative data about self-representation is not available, the available information suggests self-representation rates of $20-30 \%$ in New York, and $60 \%$ in Toronto. ${ }^{\text {vi }}$ While some litigants simply don't think they need a lawyer, most of the self-represented are deterred by the cost of hiring one. (Thompson and Reierson, 2002; Langan, 2005, p. 832) Ontario's legal aid regime funds traditional legal representation for custody and visitation disputes only for the poorest litigants. New York, by contrast, has much lower rates of self-representation, largely because indigent litigants in custody cases have a legal right to state-funded counsel. A party represented by counsel may be less likely to feel coerced by a settlement-seeking trial judge or his or her court attorney, insofar as she has an expert ally to inform her about the costs and benefits of settling or continuing to litigate.

In defending the one-judge model, New York judges alluded to the efficiency and effectiveness arguments mentioned above. One suggested that the potential for appellate review of facts found at trial is a sufficient safeguard against bias brought about by the trial judge's participation in settlement-seeking. Justice UU suggested that only the trial judge will be taken seriously by the parties in a pre-trial conference. Having a different judge conduct the conference would allow the lawyers to discount negative evaluations from that judge. The one- 
judge model makes it impossible for aggressive matrimonial lawyers to tell their clients “don't worry, he's not the real judge" and "we'll get a better judge at trial," thereby avoiding the need to make concessions. New York matrimonial attorney LL expanded on this problem with the twojudge model:

When the judge who's going to settle the case comes out against you, you say 'fine, I'll just hear what the trier of fact has to say. I'll just go to the next forum, maybe the next forum will think differently.' So you're constantly judge-shopping, and waiting for the judge that's going to agree with you, and so you wind up having to try the case.

The debate between two-judge and one-judge pre-trial conference models can be understood as a "how much justice can we afford?" question. It might be argued that the twojudge model provides a higher standard of procedural justice, but consumes more scarce judicial resources in doing so. However, it is clear that the issue cannot be analyzed without attention to self-representation rates and other broad considerations of justice system design. New York's combination of comprehensive civil legal aid with a one-judge model might deliver the best of all worlds. A proper evaluation of these efficiency and justice considerations must await future research.

\section{Best interests in Settlement}

A second issue which the empirical findings bring to light is the shaky reign of the best interests of the child standard, the titular monarch of custody and access law. There is a disjunction between the child-centered nature of custody and visitation law, and the parentcentered nature of custody and visitation procedure (Semple, 2010). This disjunction is reflected 
in judicial settlement-seeking. While the best interest of the child is the supreme legal doctrine, the attention paid to the child and her interests during the pre-trial conferences is a matter of judicial discretion. Settlement of a parenting dispute requires that either (i) the adult parties reach an agreement, or (ii) one of them abandons his or her position. It does not require the consent of the child. Parents might, hypothetically, settle their dispute in a manner which is mutually satisfactory to them, but contrary to the interests of the child.

A settlement-seeking judge in a parenting case is confronted with a choice. The judge might scrutinize all settlement alternatives according to the child's interest, and push the parties toward an arrangement which he or she feels would be best for the child. This would be consonant with the law's clear instruction that the child's interests are to be placed first. Alternatively, a settlement-seeking judge could decide that an approach mutually acceptable to the parents should be presumed to be in the child's interest. This would be consonant with the assumption generally made about parents' decisions in the absence of child protection concerns. $^{\text {vii }}$

Both approaches were evident in the comments of the judges. Ontario Superior Court judge AA said that he "always" reviews consensual parenting arrangements in a divorce, and "won't approve them without a detailed affidavit" setting out the plan. In the provincial court, Justice DD said that she will not, as a rule, agree to a consensual joint custody arrangement in any case with a history of domestic violence. However, other judges were less interventionist in this regard. Provincial court justice BB said that he "accepts the principle of parental autonomy, and parents... are deemed to make decisions in the children's best interests, and if they agree I won't go behind it." One experienced Toronto family law attorney said that she had never seen a judge reject a parenting arrangement upon which the parties agreed. 
One obvious source of information about the best interest of a child is the child him or herself. In both Ontario and New York, judges hearing custody or visitation cases have the option to interview the children involved to determine their views and preferences. ${ }^{\text {vii }}$ However, most judges in both jurisdictions said that they never or very rarely do so during the pre-trial process. Ontario judges generally do not speak to the children at all (Birnbaum and Bala, 2010), and if New York judges do so, it generally occurs after settlement-seeking has been unsuccessful and the trial has begun. Children may be represented by their own lawyers in both jurisdictions, but these lawyers are not present at the pre-trial conferences at which most judicial settlementseeking occurs.

In addition to respect for parental autonomy and desire to insulate children from the process, the ambiguity of the best interest standard is an impediment to judicial scrutiny of consensual arrangements. Even a judge who is prepared to dig below a parental agreement in pursuit of "best interests" is likely to find the quarry elusive, or not worth the chase. Ontario Superior Court Justice EE said that finding the best of all conceivable parenting schedules for the child usually “doesn't really matter to the kids, as long as they feel that some semblance of the family" will continue. According to New York judge MM,

there's a dozen different perfectly reasonable ways to resolve any of these cases ... and the fact that somebody else chooses to do it differently isn't a basis for me to interfere. I only interfere if it's substantively bad for the children, or unclear.

After four years on the bench MM could only recall one case in which she had rejected a parental agreement on the basis that it was not in the best interest of the child. However, MM does 
regularly send back agreements to litigants and their attorneys on the basis that they are not sufficiently detailed. Having seen numerous post-judgment parenting disputes attributable to insufficiently detailed parenting agreements, she now "read[s] them thinking about what's going to go wrong" and requires the agreements to explicitly engage with various potentialities.

\section{Conclusion}

This article has sought to both elucidate and problematize judicial settlement-seeking in child custody and visitation cases. The empirical research suggests that settlement-seeking is a core activity for a significant proportion of the family judges in Toronto and New York City. As predicted by the existing literature, evaluative techniques predominate. However, facilitative approaches were also cited. Some of these simply sought to identify common ground between the litigants or emphasize the cost of trial, but others pursued more ambitious goals such as reorienting the parties toward their children's interests. Although the word "mediation" raised flags for many of the interviewees, the evaluative, transformative, and facilitative techniques they described often seemed to fit within extant definitions of that word.

While the legitimacy of the judicial pursuit of settlement was a point of consensus among respondents in the two cities, opinions differ regarding the "who" and "how" of judicial settlement-seeking in custody and visitation cases. The two research sites diverge on the question of whether a single judge should both seek settlement and then later adjudicate the same case. Judges differ from each other on the appropriate way to reconcile the doctrinal supremacy of children's interests with the practical reality that it is adults who control the litigation and its settlement. Further empirical and theoretical research is needed to scrutinize these issues. More broadly, one might question the very legitimacy of judicial settlement-seeking in parenting cases, either because the system need not encourage settlement or because someone other than judges 
ought to be doing this work. While it seems inevitable that settlement-seeking will continue to be a primary part of judicial work in parenting cases, it is a worthwhile subject of scrutiny for those who value children's rights and interests.

\section{References}

Adams, W. L. "Let's Make a Deal: Effective Utilization of Judicial Settlements in State and Federal Courts." Oregon Law Review, 1993, 72 (2), 427-457.

Alexander, J. C. "Judges' Self-Interest and Procedural Rules: Comment on Macey." Journal of Legal Studies, 1994, 23 (1), 647-666.

Alfini, J. J. "Risk of Coercion Too Great: Judges Should Not Mediate Cases Assigned to them for Trial." Dispute Resolution Magazine, 1999, 6, 11-14.

American Bar Association. ABA Model Code Of Judicial Conduct: February 2007: American Bar Association, 2007. online: American Bar Association $<\mathrm{http} / / /$ www.americanbar.org/content/dam/aba/migrated/judicialethics/ABA_MCJC_approved.a uthcheckdam.pdf> (last accessed: 25 May 2011).

Anleu, S. R., and Mack, K. "Magistrates' Everyday Work and Emotional Labour." Journal of Law and Society, 2005, 32 (4), 590-614.

Artis, J. E. "Judging the Best Interests of the Child: Judges' Accounts of the Tender Years Doctrine." Law \& Society Review, 2004, 38 (4), 769-806.

Baer, H. J. "History, Process, and a Role for Judges in Mediating Their Own Cases." New York University Annual Survey of American Law, 2001, 58 (2), 131-154. 
Bailey-Harris, R., Barron, J., and Pearce, J. "Research: Settlement Culture And The Use Of The 'No Order' Principle Under The Children Act 1989." Child and Family Law Quarterly, 1999, 11 (1), 53-62.

Birnbaum, R., and Bala, N. "Judicial Interviews with Children in Custody and Access Cases: Comparing Experiences in Ontario and Ohio." International Journal of Law, Policy, and the Family, 2010, 24 (3), 330-337.

Blair, D. M., and Weiner, M. H. "Resolving Parental Custody Disputes - A Comparative Exploration." Family Law Quarterly, 2006, 39 (2), 247-266.

Brazil, W. D. "Hosting Settlement Conferences: Effectiveness in the Judicial Role." Ohio St. J. on Disp. Resol., 1987, 3 (1), 1-78.

Brunet, E. "Judicial Mediation and Signaling." Nevada Law Journal, 2002, 3 (2), 232-258.

Burns, S. "The Name of the Game Is Movement: Concession Seeking in Judicial Mediation of Large Money Damage Cases." Mediation Quarterly, 1998, 15 (4), 359-370.

Burns, S. Making Settlement Work. Burlington, VT: Ashgate, 2000.

Burns, S. "'Think Your Blackest Thoughts and Darken Them:' Judicial Mediation of Large Money Damage Disputes." Human Studies, 2001, 24 (3), 227-249.

Cavanagh, R., and Sarat, A. "Thinking About Courts: Toward and Beyond a Jurisprudence of Judicial Competence." Law and Society Review, 1980, 14 (2), 371-415. 
Colatrella, M. T. J. "Court-Performed Mediation in the People's Republic of China: A Proposed Model to Improve the United States Federal District Courts' Mediation Programs;." Ohio State Journal on Dispute Resolution, 2000, 15 (2), 391-423.

Cratsley, J. C. "Judicial Ethics and Judicial Settlement Practices: Time for Two Strangers to Meet." Ohio State Journal on Dispute Resolution, 2006, 21 (3), 569-596.

Davis, G. "The Halls of Justice and Justice in the Halls." In R. Dingwall and J. Eekelaar (ed.), Divorce Mediation And The Legal Process. New York: Oxford University Press, 1988.

Davis, G., and Pearce, J. "A View From The Trenches - Practice And Procedure In Section 8 Applications." Family Law, 1999, 29 (July), 457-466.

Evaluation Division: Office of Strategic Planning and Performance Management. The Unified Family Court Summative Evaluation Final Report. Ottawa: Department of Justice (Canada), 2009. online: DOJ <http://www.justice.gc.ca/eng/pi/eval/rep-rap/09/ufc-tuf/ufc.pdf> (last accessed: 25 May 2011).

Folberg, J., Milne, A., and Salem, P. "The Evolution of Divorce and Family Mediation: An Overview." In J. Folberg, A. Milne and P. Salem (ed.), Divorce and Family Mediation: Models, Techniques, and Applications. New York: Guilford Press, 2004.

Galanter, M. "A Settlement Judge, not a Trial Judge: Judicial Mediation in the United States." Journal of Law and Society, 1985, 12 (1), 1-18.

Goss, J. "Judicial Dispute Resolution: Program Setup and Evaluation in Edmonton." Family Court Review, 2004, 42 (3), 511-525. 
Gove, T. J. "Judge-Mediated Case Conferences in Family Law: Looking for the Best Attainable Outcome." Advocate, 1999, 57 (6), 855-859.

Guggenheim, M. What's Wrong with Children's Rights. Cambridge: Harvard University Press, 2005.

Hogan, M. R. "Judicial Settlement Conferences: Empowering the Parties to Decide Through Negotiation." Willamette Law Journal, 1991, 27 (3), 429-461.

Johnston, J. R., Roseby, V., and Kuehnle, K. In The Name of the Child : a Developmental Approach to Understanding and Helping Children of Conflicted and Violent Divorce. New York: Springer, 2009.

Lambros, T. D. "The Judge's Role in Fostering Voluntary Settlements." Villanova Law Review, 1984, $29(6), 1363-1378$.

Landerkin, H. F. "Custody Disputes in the Provincial Court of Alberta: A New Judicial Dispute Resolution Model." Alberta Law Review, 1997, 35 (3), 627-686.

Langan, A.-M. "Threatening the Balance of the Scales of Justice: Unrepresented Litigants in the Family Courts of Ontario." Queen's Law Journal, 2005, 30 (2), 825-862.

Lee, D. H. "Viewing Family Court Practice through the Prism of Purpose." Columbia Journal of Law and Social Problems, 2007, 40 (4), 647-655.

Lieff, A. H. "Pre-trial of Family Law in the Supreme Court of Ontario - Simplify and Expedite." Law Society of Upper Canada Gazette, 1976, 10 (4), 300-338. 
Menkel-Meadow, C. "For And Against Settlement: Uses And Abuses Of The Mandatory

Settlement Conference." University of California at Los Angeles Law Review, 1985, 33 (2), 485514.

Millar, P. The Best Interests of Children: an Evidence-Based Approach. Toronto: University of Toronto Press, 2009.

Mnookin, R. H., and Kornhauser, L. "Bargaining in the Shadow of the Law: The Case of Divorce." Yale Law Journal, 1979, 88 (5), 950-997.

OBA Family Law Section, ADR Institute Of Ontario, and Ontario Association Of Family Mediators (OAFM). Family Law Process Reform: Supporting Families To Support Their Children. Toronto: OAFM, 2009. online: OAFM

$<$ http://www.oafm.on.ca/Documents/OBA\%20OAFM\%20ADR\%20Institute\%20submission\%20 Apr\%207\%2009.pdf> (last accessed: 25 May 2011).

Oesterle, D. A. "Dangers of Judge-Imposed Settlement." Litigation, 1983, 9 (3), 29-57.

Otis, L., and Reiter, E. H. "Mediation by Judges: A New Phenomenon in the Transformation of Justice." Pepperdine Dispute Resolution Law Journal, 2006, (3), 351-404.

Pearce, J., Davis, G., and Barron, J. "Love In A Cold Climate - Section 8 Applications Under The Children Act 1989." Family Law, 1999, 1999 (January), 22-28.

Press, S. "Commmentary on "The Name of the Game Is Movement: Concession Seeking in Judicial Mediation of Large Money Damage Cases " Mediation Quarterly, 1998, 15 (4), 368371. 
Reece, H. "The Paramountcy Principle, Consensus or Construct?" Current Legal Problems, 1996, 49 (1), 267-304

Resnik, J. "Managerial Judges." Harvard Law Review, 1982, 96 (2), 374-448.

Resnik, J. "Trial As Error, Jurisdiction As Injury: Transforming The Meaning Of Article III." Harvard Law Review, 2000, 113 (4), 924-1035.

Riskin, L. L. "Understanding Mediators' Orientations, Strategies, and Techniques: A Grid for the Perplexed." Harvard Negotiation Law Review, 1996, 1 (Spring), 7-51.

Roberts, M. Mediation in Family Disputes: Principles of Practice. Hampshire, UK: Ashgate, 2008.

Roberts, S. "Mediation in Family Disputes." Modern Law Review, 1983, 46 (5), 537-557.

Roberts, S. "Institutionalized Settlement in England: A Contemporary Panorama." Williamette Journal of International Law \& Dispute Resolution, 2002, 10 (1), 17-35.

Robinson, P. "Adding Judicial Mediation to the Debate about Judges Attempting to Settle Cases Assigned to Them for Trial." Journal of Dispute Resolution, 2006, 2006 (2), 335-385.

Rolland, F. 2009. Mediation/arbitration in Family Law: Pros and Cons (Winkler Lecture on Civil Justice Reform), at Ottawa, Canada. online: University of Ottawa Faculty of Law $<$ http://www.commonlaw.uottawa.ca/en/news/common-law-section-news/third-annual-warrenwinkler-lecture-alternative-ideas-for-civil-justice-reform.html> (last accessed: 25 May 2011).

Salem, P. "The Emergence of Triage in Family Court Services: The Beginning of the End for Mandatory Mediation?" Family Court Review, 2009, 47 (3), 371-388. 
Sander, F. E. A. "A Friendly Amendment." Dispute Resolution Magazine, 1999, 6 (Fall), 11-14.

Schepard, A. "The Evolving Judicial Role in Child Custody Disputes: From Fault Finder to Conflict Manager to Differential Case Management." University of Arkansas at Little Rock Law Review, 2000, 22 (3), 395-428.

Semple, N. "Whose Best Interests? Custody and Access Law and Procedure." Osgoode Hall Law Journal, 2010, 48 (2), 287-336.

Silbermann, J. W. "Child Custody in Contested Matrimonials." New York State Bar Association Journal, 2008, 80 (1),

Spinak, J. "Reforming Family Court: Getting it Right between Rhetoric and Reality." Washington University Journal of Law \& Policy, 2009, 31 (1), 11-38.

Stevenson, M., Watson, G. D., and Weissman, E. "The Impact of Pretrial Conferences: An Interim Report on the Ontario Pretrial Conference Experiment." Osgoode Hall Law Journal, $1977,15(3), 591-615$.

Thompson, D. A. R., and Reierson, L. "A Practicing Lawyer's Field Guide to the Unrepresented." Canadian Family Law Quarterly, 2002, 19 (3), 529-546.

Tornquist, L. J. "The Active Judge in Pretrial Settlement: Inherent Authority Gone Awry." Willamette Law Review, 1989, 25 (4), 743-775.

Trinder, L., Connolly, J., Kellet, J., Notley, C., and Swift, L. Making Contact Happen or Making Contact Work? The Process and Outcomes of In-court Conciliation. London: Department of 
Constitutional Affairs (UK), 2006. online: DCA

$<$ http://www.dca.gov.uk/research/2006/03_2006.pdf> (last accessed: 25 May 2011).

Trinder, L., and Kellett, J. "Fairness, Efficiency And Effectiveness In Court-Based Dispute

Resolution Schemes In England." International Journal of Law, Policy and the Family, 2007, 21

(3), 322-340.

Welsh, N. A. "The Thinning Vision of Self-Determination in Court-Connected Mediation: The

Inevitable Price of Institutionalization?" Harvard Negotiation Law Review, 2001, 6 (1), 1-96.

Zumeta, Z. 2000. "Styles of mediation: Facilitative, evaluative, and transformative mediation."

National Association for Community Mediation Newsletter, Fall, 2000.

\footnotetext{
${ }^{\mathrm{i}}$ Child custody and visitation matters are not heard by juries in Ontario or New York State.

${ }^{i i}$ Ethics approval was granted for the interviews by the York University Human Participants Review SubCommittee. (Certificate Number 2009-161, granted on November 25, 2009.)

iii Even more subtle than hedged evaluations are evaluations through evaluative "signalling." According to Brunet, judicial "signalling ... can be oral, through body language, or facial expressions; it can be so subtle (such as a scowl) that an advocate may fail to perceive it; or a judge's blank look or raised eyebrow when confronted with a hard to understand argument can be ambiguous and misunderstood" (Brunet, 2002, p. 252).

iv For example: "(5) The child is not a chattel, or a toy, or a prize for the successful party in a defended divorce case," and "(9) animosity, bickering, bitterness, hostility and hurling vile accusations at each other will not help the morale of the children. Parents have to develop a harmonious relationship that will last after the divorce." (Lieff, 1976, p. 314-315.)

${ }^{\mathrm{v}}$ However, TT added that as a private sector mediator she always seeks to ensure that the parties are aware of the legal rights which they are compromising.

${ }^{v i}$ Regarding self-representation in Toronto family courts, see Evaluation Division: Office of Strategic Planning and Performance Management, 2009 and OBA Family Law Section, ADR Institute Of Ontario, and Ontario Association Of Family Mediators, 2009, p. 6.

${ }^{\text {vii }}$ This proper degree of judicial interventionism in parenting cases became a live issue in Ontario in 2008 following the death of seven-year old Katelynn Sampson. With her mother's consent, custody of Sampson had been transferred to a woman named Donna Irving. There was very minimal judicial scrutiny of the new living arrangements, and Irving and her live-in boyfriend were subsequently charged with Katelynn's murder. This episode created a public outrage and led to amendments to the Children's Law Reform Act.

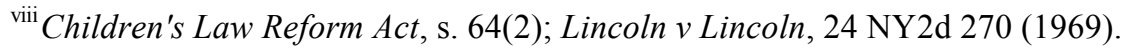

